\title{
PERSEPSI WISATAWAN JEPANG TERHADAP KUALITAS PELAYANAN PRAMUWISATA JEPANG PADA PT. JTB BALI
}

\author{
I Putu Takahide Valentino ${ }^{1}$, I Made Sendra ${ }^{2}$, Luh Gede Leli Kusuma Dewi ${ }^{3}$ \\ ${ }^{1}$ Email: ptv0214@yahoo.com \\ Program Studi S1 Industri Perjalanan Wisata, Fakultas Pariwisata, Universitas Udayana \\ ${ }^{2}$ Email: sendramade65@gmail.com \\ Program Studi S1 Industri Perjalanan Wisata, Fakultas Pariwisata, Universitas Udayana \\ ${ }^{3}$ Email: leli.kusumadewi@gmail.com \\ Program Studi S1 Industri Perjalanan Wisata, Fakultas Pariwisata, Universitas Udayana
}

\begin{abstract}
The purpose of this research is to know how the perception from the tourist to the quality services Japan guide PT. JTB Bali and know complaints from quality service the guide so that the company can improve the quality of their service to the tourists. In this study used primary data and secondary data. The technique of data collection conducted with observation, in-depth interviews and dissemination of the questionnaire. Sampling techniques using a purposive sampling while the data analysis techniques used are qualitative and descriptive analysis with the likert scale. The results of this research, the satisfaction of tourist in positions quite agree because still there is not enough good judgment given by the tourists. In addition the results of interviews conducted with the authors Japan pramuwisata there is still unknown, constraints and complaints pramuwisata so that it affects them when serving the tourists who use the products and services of PT. JTB Bali.
\end{abstract}

Abstrak: Tujuan dari penelitian ini adalah untuk mengetahui bagaimana persepsi watawan Jepang terhadap kualitas pelayanan pramuwisata Jepang pada PT. JTB Bali serta mengetahui kendala ataupun keluhan dari pramuwisata sehingga perusahaan dapat memperbaiki kualitas pelayanan mereka kepada wisatawan. Penelitian ini menggunakan data primer dan data sekunder. Teknik pengumpulan data dilakukan dengan observasi, wawancara mendalam dan penyebaran kuisioner. Teknik pengambilan sampel menggunakan purposive sampling sedangkan teknik analisis data yang digunakan adalah analisis deskriptif kualitatif menggunakan dengan Skala Likert. Hasil dari penelitian ini kepuasan wisatawan berada pada posisi cukup setuju, karena masih terdapatnya penilaian yang belum cukup baik yang diberikan oleh wisatawan. Selain itu dari hasil wawancara yang dilakukan penulis dengan pramuwisata Jepang, diketahui masih terdapatnya kendala dan keluhan pramuwisata sehingga mempengaruhi mereka ketika melayani wisatawan yang menggunakan produk dan jasa PT. JTB Bali.

Keywords: tourist perception, quality of service.

\section{PENDAHULUAN}

Perkembangan pariwisata di Indonesia saat ini telah menyebar ke semua daerah termasuk Bali. Bali yang merupakan salah satu daerah andalan bagi pariwisata Indonesia memiliki keunikan khas seperti keindahan alam, adat istiadat dan budaya yang berbeda dengan daerah lainnya, sehingga pariwisata di Bali dikenal sebagai pariwisata alam dan budaya. Keunikan tersebut yang membuat Bali hingga kini masih bertahan dan terus bersaing dalam perkembangan pariwisata dunia.

Salah satu wisatawan yang banyak mengunjungi Bali adalah wisatawan yang 
berasal dari Jepang. Dari data Dinas Pariwisata Provinsi Bali pada tahun 2015 diketahui wisatawan Jepang berada dalam empat besar tingkat kunjungan wisatawan mancanegara yang datang langsung ke Bali sebagai tempat tujuan wisata mereka, namun dalam 5 tahun terakhir wisatawan Jepang yang datang ke Bali mengalami peningkatan yang tidak terlalu signifikan, apabila dibandingkan dengan wisatawan yang berasal dari negara lain, pertumbuhan wisatawan Jepang yang datang ke Bali masih jauh dibawah dari yang ditargetkan oleh pemerintah. Pertumbuhan wisatawan Jepang yang datang ke Bali tidak terlalu signifikan tersebut tidak terlepas dari pengaruh krisis ekonomi global dunia dan membaiknya ekonomi Amerika Serikat pada pertengahan tahun 2014, mata uang dollar menguat yang berpengaruh terhadap perekonomian Asia Pasifik yang dimotori Jepang dan China, sehingga perekonomian masyarakat Jepang ikut berpengaruh. Selain itu, hingga saat ini pesawat tujuan langsung dari Jepang ke Bali tidak terlalu banyak sehingga berdampak tinggi nya harga tiket pesawat tersebut dan calon wisatawan Jepang tersebut lebih memilih tujuan wisata yang lebih murah. Hal lain yang membuat pertumbuhan wisatawan Jepang yang datang ke Bali tidak terlalu signifikan adalah ketika wisatawan Jepang yang telah datang ke Bali mendapatkan kurangnya pelayanan dan penjelasan yang diberikan biro perjalanan wisata ataupun pemandu wisata sehingga menyebabkan rasa puas dalam tingkat pelayanan yang diberikan tidak terpenuhi.

Dapat diketahui bahwa bagian penting dari sebuah biro perjalanan wisata adalah pramuwisata yang selalu bersentuhan langsung dengan konsumen yaitu wisatawan. Wisatawan dapat terpuaskan atau terpenuhi keinginannya juga dapat ditentukan dari pelayanan pramuwisata terhadap wisatawan tersebut. Bila pelayanan yang diberikan sesuai keinginan atau ekspektasi, maka kepuasan wisatawan tersebut tentunya juga akan berdampak baik. Dalam jurnal
Internasional yang ditulis oleh Eraqi (2006) "Tourism services quality (Tour Serv Qual) in Egypt" yang memfokuskan bagaimana kualitas pelayanan yang diberikan kepada wisatawan oleh pelaku pariwisata di Kairo Mesir dapat membuat wisatawan menjadi puas dengan hal tersebut dapat membuat jumlah kunjungan wisatawan datang ke tempat destinasi tersebut bertambah karena pelayanan yang diberikan sangat memuaskan dan tidak ada masalah didalam pelayanan tersebut, selain itu penelitian ini juga memberikan gambaran bagaimana tingkat kepuasan wisatawan yang berkunjung ke Mesir dengan dilakukan pengukuran data dengan menggunakan skala likert dari faktor eksternal dan internal.

Salah satu biro perjalanan wisata yang terkemuka dan sudah banyak diketahui wisatawan Jepang khususnya adalah PT. JTB Bali. Saat ini, PT. JTB Bali terus mengupayakan peningkatan pelayanan di segala fasilitas bagi wisatawan Jepang yang menggunakan jasa dan produk mereka demi meningkatnya jumlah kunjungan wisatawan Jepang ke Bali dan yang menggunakan jasa mereka. PT. JTB Bali saat ini juga mengalami masalah dalam pelayanan termasuk complaint dan bad comment dari wisatawan Jepang terhadap pramuwisata Jepang pada PT. JTB Bali.

Untuk mengatasi permasalahan dari menurunnya jumlah wisatawan Jepang yang menggukanan jasa PT. JTB Bali karena sering terjadinya complaint dari wisatawan terhadap pelayanan pramuwisata maka diperlukan sebuah pemecahan masalah yang tepat untuk mengetahui persepsi wisatawan Jepang terhadap pramuwisata Jepang PT.JTB Bali dan apa saja kendala dari pramuwisata tersebut guna mengetahui dan memperbaiki pelayanan kepada wisatawan Jepang yang lebih terarah sesuai dengan permasalahan yang terjadi. 


\section{METODE}

Untuk membatasi permasalahan dalam penelitian ini, maka digunakan definisi operasional variabel. Variabel penelitian tersebut adalah persepsi wisatawan Jepang Terhadap Kualitas Pelayanan Pelayanan Pramuwisata Jepang pada PT. JTB Bali yang menggunakan model TERRA yang terdiri dari:

\begin{tabular}{|c|c|c|}
\hline No & Variabel & Indikator \\
\hline 1 & $\begin{array}{l}\text { Bukti } \\
\text { Langsung } \\
\text { (Tangibles) }\end{array}$ & $\begin{array}{l}\text { 1. Kebersihan pramuwisata. } \\
\text { 2. Seragam pramuwisata. } \\
\text { 3. Kelengkapan fasilitas } \\
\text { pendukung pramuwisata. } \\
\text { 4. Bahasa yang digunakan } \\
\text { pramuwisata dalam } \\
\text { memberikan informasi } \\
\text { kepada wisatawan. }\end{array}$ \\
\hline 2 & $\begin{array}{l}\text { Empati } \\
\text { (Empaty) }\end{array}$ & $\begin{array}{l}\text { 1.Pelayanan yang ramah } \\
\text { kepada wisatawan saat } \\
\text { melakukan tour. } \\
\text { 2.Perhatian terhadap } \\
\text { kegiatan tour dalam } \\
\text { memenuhi kebutuhan } \\
\text { wisatawan. } \\
\text { 3. Kesopanan pramuwisata } \\
\text { dalam berkomunikasi } \\
\text { dengan wisatawan. } \\
\text { 4. Sikap pramuwisata dalam } \\
\text { menerima kritik dan saran } \\
\text { dari wisatawan. }\end{array}$ \\
\hline 3 & $\begin{array}{l}\text { Daya } \\
\text { Tanggap } \\
\text { (Responsivn } \\
\text { ess) }\end{array}$ & $\begin{array}{l}\text { 1. Tidak ragu didalam } \\
\text { memberikan pelayanan. } \\
\text { 2. Membantu wisatawan pada } \\
\text { saat membutuhkan } \\
\text { pertolongan. } \\
\text { 3. Memberikan informasi } \\
\text { yang jelas mengenai tour } \\
\text { package yang dibeli oleh } \\
\text { wisatawan. } \\
\text { 4. Cepat memahami dan } \\
\text { menangani keluhan dari } \\
\text { wisatawan. }\end{array}$ \\
\hline 4 & $\begin{array}{r}\text { Keandalan } \\
\text { (Reliability) }\end{array}$ & $\begin{array}{l}\text { 1. Efisiensi waktu dalam } \\
\text { kegiatan check in-out dan } \\
\text { tour. } \\
\text { 2. Proses pelaksanaan tour } \\
\text { sesuai dengan itinerary } \\
\text { yang sudah disepakati. } \\
\text { 3.Pramuwisata } \\
\text { melaksanakan pekerjaan } \\
\text { sesuai dengan SOP. }\end{array}$ \\
\hline
\end{tabular}

\begin{tabular}{cc}
\hline Jaminan & 1. Wisatawan tidak merasa \\
(Assurance) & terganggu saat \\
& melaksanakan kegiatan \\
& tour. \\
& 2. Meningkatkan \\
& keselamatan dalam \\
melaksanakan tour. & 3. Selalu menginformasikan \\
untuk menjaga keamanan & barang-barang bawaan \\
& wisatawan saat \\
melaksanakan tour. \\
4.Adanya perlengkapan \\
kesehatan (P3K) dalam \\
melaksanakan tour.
\end{tabular}

Data kualitatif dalam penelitian ini berupa pembahasan kualitas pelayanan pramuwisata Jepang terhadap wisatawan yang menggunakan jasa PT. JTB Bali, sedangkan data kuantitatif pada penelitian ini yaitu data yang berupa angka-angka dari perhitungan atau pengukuran seperti data jumlah pengguna jasa PT. JTB Bali dan skor penilaian wisatawan Jepang terhadap pramuwisata Jepang PT. JTB Bali.

Sumber data dalam penelitian ini menggunakan dua jenis data, yaitu data primer dan data sekunder. Data primer adalah data yang dikumpulkan langsung dari lokasi penelitian meliputi persepsi wisatawan Jepang terhadap pelayanan yang di berikan oleh pramuwisata Jepang terhadap wisatawan yang menggunakan jasa PT. JTB Bali, sedangkan data sekunder adalah data yang diperoleh dari sumber-sumber selain di lokasi penelitian, data ini di dapatkan melalui perpustakaan, literatur-literatur atau bahan-bahan tertulis lainya yang sesuai dengan permasalahan yang diangkat dalam penelitian.

Pengumpulan data dalam penelitian ini menggunakan beberapa teknik sebagai berikut.

1. Observasi, melalui dua cara yaitu observasi secara sistematis dan observasi secara partisipasi. Observasi secara sestematis yaitu dengan penentuan status dan permasalahan yang diteliti pada objek penelitian ini, 
sedangkan observasi partisipasi digunakan untuk mengetahui pelayanan informan kunci yaitu pramuwisata saat melakukan tour dengan wisatawan Jepang.

2. Wawancara, yaitu dengan cara melakukan tanya jawab langsung kepada pihak manajemen pada PT. JTB Bali untuk mendapatkan data yang diperoleh pada saat observasi dengan menitikberatkan daftar pertanyaan yang telah disiapkan sebelumnya.

3. Kuisioner, yaitu teknik pengumpulan data dengan cara menyusun daftar pertanyaan yang telah dipersiapkan sebelumnya ditujukan kepada responden untuk memperoleh data mengenai terhadap kualitas pelayanan pramuwisata Jepang terhadap wisatawan yang menggunakan jasa pada PT. JTB Bali. Kuisioner ini adalah kuisioner terstruktur yang artinya responden diberikan alternatif jawaban untuk memilih dari beberapa jawaban yang telah disediakan.

4. Studi Kepustakaan, yaitu pengumpulan data dengan cara mengkaji dan mengambil dari beberapa literatur dan buku-buku, arsip, serta bahan tertulis lainnya yang berkaitan atau yang relevan dengan objek penelitian. Data itu berupa teori-teori atau konsepkonsep yang dibahas dalam permasalahan seperti pengertian dari tingkat kepuasan wisatawan, kualitas pelayanan, dan hasil-hasil penelitian sebelumnya yang memiliki relevansi dengan permasalahan yang diangkat untuk memperkuat data penelitian.

Teknik pengambilan sampel dalam penelitian ini menggunakan purposive sampling. Dalam penelitian ini, yang akan dijadikan penentuan sampel adalah wisatawan Jepang pengguna jasa PT. JTB Bali. Untuk menentukan jumlah wisatawan yang akan diberikan kuesioner mengenai persepsi wisatawan terhadap pelayanan yang diberikan oleh pramuwisata Jepang yaitu menggunakan model (Supranto, 2006: 243) dimana mengalikan 5 sampai
10 dengan jumlah pertanyaan (indikator) dalam kuisioner. Dalam penelitian ini jumlah variabel 5 dan jumlah indikator 19, maka jumlah responden yang dijadikan sampel sebanyak 95 yang didapat dari mengalikan 5 dengan 19 indikator atau pernyataan dalam kuisioner.

Untuk menganalisis hasil kuesioner yang telah dilakukan kepada wisatawan Jepang terhadap kualitas pelayanan pramuwisata PT. JTB di Bali digunakan cara pengukuran sikap secara langsung yaitu dengan menggunakan skala likert Likert (Suwitra, 2002:26). Masing-masing pernyataan diberika skor sebagai berikut:

1. Skor lima diberikan apabila responden memberikan tanggapan atau penilaian sangat setuju.

2. Skor empat diberikan apabila responden memberikan tanggapan atau penilaian yang setuju

3. Skor tiga diberikan apabila responden memberikan tanggapan atau penilaian yang cukup setuju

4. Skor dua diberikan apabila responden memberikan tanggapan atau penilaian yang tidak setuju.

5. Skor satu diberikan apabila respoden memberikan tanggapan atau penilaian sangat tidak setuju.

Berdasarkan hasil penilaian tingkat kepentingan/harapan dan hasil penilaian terhadap persepsi tentang kualitas pelayanan maka akan dihasilkan suatu perhitungan melalui tingkat pelaksanaan kualitas pelayanan pramuwisata dari PT. JTB Bali, tingkat kesesuaian adalah hasil perbandingan skor kinerja yang di persepsikan dengan skor kepentingan atau yang diharapkan.

\section{HASIL DAN PEMBAHASAN}

Hasil penelitian terhadap 95 sampel penelitian dengan 5 karakteristik wisatawan yang menggunakan produk dan jasa pada PT. JTB Bali, didominasi oleh wisatawan dengan jenis kelamin perempuan, rentang usia diatas 40 tahun, memiliki mata pencaharian sebagai pekerja swasta, dengan tingkat pendidikan 
S1 dan memiliki tujuan ke Bali adalah untuk jalan-jalan.

Tipologi yang dimaksud dalam penelitian ini adalah klasifikasi atau pengelompokkan dari wisatawan Jepang yang membentuk suatu pola yang menggambarkan mengenai perilaku, tempat yang dikunjungi serta aktivitas wisatawan Jepang ketika berkunjung ke Bali. Apabila dikelompokkan secara keseluruhan, wisatawan Jepang yang datang ke Bali umumnya adalah dengan usia dewasa, dengan jenis kelamin wanita yang lebih mendominasi, dengan profesi sebagai pekerja swasta, dengan motivasi berkunjung ke Bali adalah untuk berlibur, tempat yang lebih banyak dikunjungi adalah melihat keindahan alam Bali, datang ke Bali lebih banyak dengan group dibandingkan perorangan sesuai dengan hasil pada penelitian yang telah dilakukan.

Dari hal tersebut, diketahui jika wisatawan Jepang berkunjung ke Bali masuk dalam kategori Individual Mass Tourist menurut Cohen (1972) yaitu wisatawan yang menyerahkan pengaturan perjalanannya kepada agen perjalanan dan mengunjungi daerah tujuan wisata yang sudah terkenal, namun bila dilihat berdasarkan perilaku wisatawan menurut Gray (1970), wisatawan Jepang termasuk kedalam sunlust tourist, yaitu wisatawan yang berkunjung ke suatu daerah dengan tujuan utama untuk beristirahat atau relaksasi, sehingga mereka umumnya mengunjungi DTW yang mempunyai ciri multiple $S$ (sun, sea, sand).

Dari hasil persepsi wisatawan dalam 5 variabel kualitas pelayanan pramuwisata Jepang pada PT. JTB Bali, dapat diketahui pada variabel Tangibles, penilaian tertinggi yang diberikan oleh wisatawan Jepang terhadap bukti langsung dari pramuwisata tersebut adalah seragam yang dikenakan sudah rapih dan bersih. Dari penilaian tersebut diketahui jika seragam yang dikenakan pramuwisata sangat diperhatikan oleh wisatawan, namun bahasa pramuwisata ketika menjelaskan kepada wisatawan dirasakan kurang memuaskan wisatawan sehingga penilaian yang mereka berikan, bahasa pramuwisata dalam menyampaikan informasi mendapatkan penilaian yang belum baik dari wisatawan.

Pada variabel variabel Emphaty, indikator yang menjadi penilaian tertinggi wisatawan adalah pramuwisata mau menerima kritik dan saran apabila ada keluhan dari wisatawan namun yang menjadi penilaian terendah pada variabel Emphaty menurut wisatawan adalah pramuwisata tidak memberikan perhatian yang baik kepada wisatawan.

Pada variabel Responsiviness, terdapat dua indikator yang menjadi penilaian tertinggi dari wisatawan, yaitu pramuwisata senantiasa membantu wisatawan ketika membutuhkan pertolongan dan indikator pramuwisata mampu menjelaskan dengan tepat dan jelas terhadap tour package yang dibeli. Sedangkan penilaian terendah yang diberikan wisatwan dalam variabel Responsiviness adalah pramuwisata sigap dalam memberikan pertolongan kepada wisatawan.

Pada variabel Realibility dapat dikeahui jika indikator pramuwisata sudah sesuai dengan itinerary terhadap tour package yang dibeli merupakan penilaian tertinggi yang diberikan wisatawan, sedangkan penilaian terendah dari penilaian wisatawan adalah pramuwisata telah bekerja sesuai dengan SOP yang ada. Untuk variabel Assurance diketahui jika indikator wisatawan merasa nyaman dan tidak terasa terganggu selama tour berlangsung merupakan penilaian tertinggi yang diberikan oleh wisatawan.

Dari hasil wawancara dengan pramuwisata Jepang PT. JTB Bali saat menangani wisatawan Jepang, dapat diketahui terdapatnya keluhan terhadap pelayanan yang diberikan pramuwisata saat tour berlangsung. Untuk menangani complaint tersebut, pramuwisata menjelaskan kepada wisatawan apabila dalam tour dalam group pramuwisata juga memperhatikan wisatawan lainnya dan 
tidak bisa perduli dengan beberapa orang saja serta meminta maaf kepada wisatawan yang bersangkutan apabila kurang memberikan pelayanan yang baik.

Dalam hal fasilitas yang diberikan perusahaan, menurut pramuwisata sudah memenuhi namun belum sangat memuaskan, misalnya Mic dan Toa yang dipakai sering rusak seperti baterai yang habis sebelum dipakai, atau Mic di dalam kendaraan yang sudah rusak namun belum dilakukan penggantian, transportasi yang kadang-kadang bermasalah (mogok), voucher untuk wisatawan yang kadangkadang kurang, seperti jumlah voucher yang diberikan staff operasional sebelum pramuwisata berangkat tour tidak sesuai dengan jumlah wisatawan dalam satu group. Untuk memberikan pelayanan yang baik kepada wisatawan, saran yang pramuwisata berikan kepada perusahaan adalah dengan lebih mempersiapkan fasilitas-fasilitas penunjang pramuwisata untuk memberikan pelayanan yang maksimal kepada wisatawan, memeriksa alat kelengkapan agar tidak terjadi kerusakan saat tour berlangsung ataupun kekurangan jumlah voucher untuk wisatawan, kendaraan cadangan yang siap sedia, sehingga ketika terjadi kerusakan saat kendaraan yang digunakan untuk tour, waktu wisatawan tidak terbuang percuma untuk menunggu perbaikan. Selain itu, sering terlambatnya komisi pramuwisata keluar dan tanggapan yang lama dari bagian operasional ketika terjadi permasalahan saat tour berlangsung merupakan keluhan dari pramuwisata tersebut.

\section{SIMPULAN}

Berdasarkan hasil dari pembahasan persepsi wisatawan Jepang terhadap kualitas pelayanan pramuwisata Jepang PT.JTB Bali dengan menggunakan metode TERRA yang pengambilan data melalui kuesioner serta dianalisis dengan menggunakan skala likert, maka dapat diperoleh kesimpulan yaitu pada variabel Tangibles, diketahui indikator yang menjadi penilaian terbaik dari wisatawan adalah seragam yang dikenakan pramuwisata sudah rapih dan bersih. Pada variabel Emphaty, diketahui penilaian terbaik adalah pramuwisata mau menerima kritik dari wisatawan. Pada variabel Responsiveness, penilaian terbaik dari wisatawan yaitu pramuwisata senantiasa membantu apabila wisatawan memerlukan pertolongan dan juga pramuwisata mampu menjelaskan dengan tepat dan jelas mengenai paket wisata yang dibeli oleh wisatawan. Pada variabel Realiability, diketahui jika indikator yang menjadi penilaian terbaik dari wisatawan adalah pramuwisata sudah sesuai dengan itinerary terhadap paket wisata yang dibeli oleh wisatawan. Pada variabel Assurance, penilaian terbaik dari wisatawan adalah wisatawan sudah merasa nyaman dan tidak terganggu saat tour berlangsung.

Sedangkan dari hasil wawancara terhadap pramuwisata Jepang PT. JTB Bali saat menangani wisatawan Jepang, dapat diketahui terdapatnya keluhan terhadap pelayanan yang diberikan pramuwisata saat tour berlangsung. Untuk menangani complaint tersebut, pramuwisata menjelaskan kepada wisatawan apabila dalam tour dalam group pramuwisata juga memperhatikan wisatawan lainnya dan tidak bisa perduli dengan beberapa orang saja serta meminta maaf kepada wisatawan yang bersangkutan apabila kurang memberikan pelayanan yang baik.

Dalam hal fasilitas yang diberikan perusahaan, menurut pramuwisata sudah memenuhi namun belum sangat memuaskan, misalnya Mic/Toa yang diberikan perusahaan sering bermasalah, transportasi yang terkadang bermasalah (mogok), voucher untuk makan wisatawan yang tidak sesuai dengan jumlah. Untuk memberikan pelayanan yang baik kepada wisatawan, saran yang pramuwisata berikan kepada perusahaan adalah kendaraan cadangan yang siap sedia, sehingga ketika terjadi kerusakan saat kendaraan yang digunakan untuk tour, 
waktu wisatawan tidak terbuang percuma untuk menunggu perbaikan. Selain itu, sering terlambatnya komisi pramuwisata keluar dan tanggapan yang lama dari bagian operasional ketika terjadi permasalahan saat tour berlangsung merupakan keluhan dari pramuwisata tersebut.

\section{SARAN}

Sebaiknya pihak manajemen PT. JTB Bali lebih memperhatikan dan meninngkatkan lagi pelayanan maupun memperbaiki dari kendala-kendala yang muncul ketika memberikan pelayanan. Meskipun pramuwisata yang berada terdepan dalam memberikan pelayanan, sebaiknya pramuwisata tersebut juga perlu dievaluasi ataupun lebih diberikan pelatihan lagi, sehingga ketika memberikan pelayanan kepada wisatawan tidak mendapatkan complaint kembali yang dapat merugikan perusahan pada akhirnya. Karena pada hasil frekuensi persepsi wisatawan tersebut, masih banyak didapatkan hasil yang belum cukup baik dari penilaian wisatawan.

Selain memberikan pelatihan dan evaluasi kepada pramuwisata, manajemen PT. JTB Bali juga perlu mendengarkan keluhan-keluhan pramuwisata dan yang menjadi kendala pramuwisata di lapangan, karena pramuwisata tersebut juga memerlukan support dari perusahaan, bila hal tersebut dapat diperbaiki dan hubungan antara pramuwisata dengan manajemen PT. JTB Bali terbima dengan baik, tentunya permasalaham-permasaahn yang terjadi ketika pramuwisata sedang menjalankan tour dengan wisatawan dapat diantisipasi dan diminimalisir, sehingga diperlukannya penelitian lanjutan untuk mengukur kualitas kinerja pramuwisata PT. JTB Bali. 


\section{Kepustakaan}

Damardjati, R.S. 2001. Istilah-Istilah Dunia Pariwisata. Jakarta : Pradnya Paramita.

Eraqi MI, "Tourism Services Quality (Tour Serv Qual) In Egypt: The Viewpoints Of External And Internal Customers". Benchmarking: An International Journal 2006; 13(4):469-92.

Kusmayadi dan Sugiarto, Endar. 2000. Metodelogi Penelitian dalam Bidang Kepariwisataan. Jakarta : PT. Gramedia Pustaka Utama.

Maleong, Lexy. 2005. Metode Penelitian Kualitatif. Bandung : PT. Remaja Rosdakarya.

Muljadi, A.J. 2010. Kepariwisataan dan Perjalanan. Jakarta : Rajawali Pers.

Pitana I Gde, Putu G Gayatri. 2005. Sosiologi Pariwisata. C.V And Offset.

Rangkuti, Fredy. 2002. Teknik Mengukur Dan Strategi Meningkatkan Kepuasan Pelanggan Dan Analisis Kasus PLN-JP. PT. Gramedia Pustaka Utama, Jakarta

Rangkuti, Freddy. 2003. Measuring Customar Satisfaction, Gaining Customer Relationship Strategy, Jakarta PT Gramedia Pustaka Utama.

Sarwono, Sarlito Wirawan. 2002. Psikologi Sosial Individu dan TeoriTeori Psikologi Sosial. Jakarta : Balai Pustaka.

Supranto. 2006. Pengukuran Tingkat Kepuasan Penggan Untuk Menaikkan Pangsa Pasar. Jakarta : PT Rineka Cipta.

Tjiptono, Fandy. 2005. Prinsip-Prinsip Total Quality Service. Jakarta : Gramedia 